\title{
RECUPERAÇÃO DE CÓRREGOS URBANOS DA BARRA FUNDA COMO CONTRIBUIÇÃO PARA A MOBILIDADE SUSTENTÁVEL
}

\author{
Brigitte Langreney* e Regina Quartim Barbosa Rioli** \\ *Arquiteta e urbanista, graduada pela Faculdade de Arquitetura e Urbanismo da Fundação Armando \\ Álvares Penteado - FAAP - E-mail: arqbri@hotmail.com \\ ${ }^{* *}$ Arquiteta e urbanista, graduada pela Faculdade de Arquitetura e Urbanismo da Faculdade de Belas \\ Artes de São Paulo - Febasp - E-mail: reginaqb@hotmail.com
}

\section{RESUMO}

O intenso processo ce urbanização das cidades, em função dos automóveis, já apresenta nítidos sinais de decadência, na nossa atual civilização, e a questão da mobilidade urbana sustentável começa a ganhar espaço e valor, no planejamento das cidades. A ideia de recuperar os córregos da região da Barra Funda, na cidade de São Paulo, e aproveitar suas margens revitalizadas para a mobilidade sustentável, constitui o objetivo desta pesquisa. Caminhar a pé, correr e andar de bicicleta,são atividades que contemplam a mobilidade sustentável. Além da preocupação social, ambiental e econômica, que formam o tripé da sustentabilidade, é preciso que haja uma nova visão de mundo, com outro olhar sobre a ocupação urbana. A recuperação de córregos urbanos providencia esta releitura de espaço, hoje uma tendência mundial, quando se pensa em planejamento urbano sustentável.

Palavras-chave: recuperação de córrego, projeto sustentável, mobilidade urbana.

\section{RECUPERATION OF URBAN STREAMS AT BARRA FUNDA DISTRICT AS A CONTRIBUTION TO THE SUSTAINABLE MOBILITY}

\begin{abstract}
The intense and growing process of cities urbanization, due to the increase of cars, already shows clear signs of decay in our civilization and the issue of sustainable urban mobility begins to gain space and value in the planning of cities. The idea to recupe-
\end{abstract}


rate the streams at Barra Funda District in São Paulo, seizing its revitalized banks for sustainable mobility, is the objective of this research. Walking, running and cycling are activities that include sustainable mobility. Besides the social, environmental and economic concerns, which form the tripod of sustainability, there must have a new vision of the world with another look on the urban occupation. The restoration of urban streams provides a new vision of the site, a worldwide trend nowadays, when sustainable urban planning is focused.

Key words: Stream Recovery, Sustainable Project, Urban Mobility.

\section{INTRODUÇÃO}

O bairro da Lapa fica localizado na zona oeste do Município de São Paulo, capital do Estado de São Paulo - Brasil. O distrito da Barra Funda faz parte da administração regional da Lapa, e fica entre o rio Tietê e a Rua Turiassú. Foram nos últimos 50 anos que o local sofreu maior crescimento urbano, devido a fatores econômicos, industrialização e também por ser um dos últimos locais com espaço disponível, próximo ao centro da cidade.

A área é cortada por uma linha férrea com estação de trem, que data de 1867 e liga Santos a Jundiaí. Hoje, este local deu lugar ao terminal intermodal da Barra Funda, o qual dispõe para a população ônibus, trem e metrô. Hoje por ser zona mista, possui nos seus arredores comércio, residências e equipamentos culturais como o Memorial da América Latina, diversas escolas profissionalizantes e universidades.

O objeto de estudo desta pesquisa é a área que fica na região da Barra Funda, entre as avenidas marginais do rio Tietê e o Parque da Água Branca. O relevo é plano próximo ao rio e possui diversos córregos que nascem nas cotas mais altas, não muito distantes do local. A linha férrea já está em um nível acima do rio, sobre os antigos terraços que circundam o rio Tietê, assim como a maioria das ruas e edificações da cidade. A parte mais plana entre a ferrovia e o rio, no passado atraiu indústrias, que se beneficiavam da água do rio e do transporte do trem, dando início assim à ocupação urbana das margens dos córregos da região.

A questão é pensar a cidade com respeito ao meio ambiente, através de uma releitura do espaço urbano atual, que apresenta seus córregos canalizados ou degradados, 
sem boas propostas de uso, e analisar a possibilidade de inserir nos novos projetos urbanos existentes para este local, os aspectos de lazer, valorização da caminhada e do uso da bicicleta para recriar um ambiente mais naturalizado, esquecido pela cidade neste processo de desprezo da natureza, devido a pavimentação do solo e desenho urbano em função do automóvel.

É preciso resgatar este potencial de ambiente natural que os córregos ainda oferecem. Não somente através da recuperação de seu trecho não canalizado, mas buscar sua nascente e traçado original como patrimônio ecológico em respeito à identidade local, a qual se perdeu ao longo da história da cidade e também como ideal de sustentabilidade urbana.

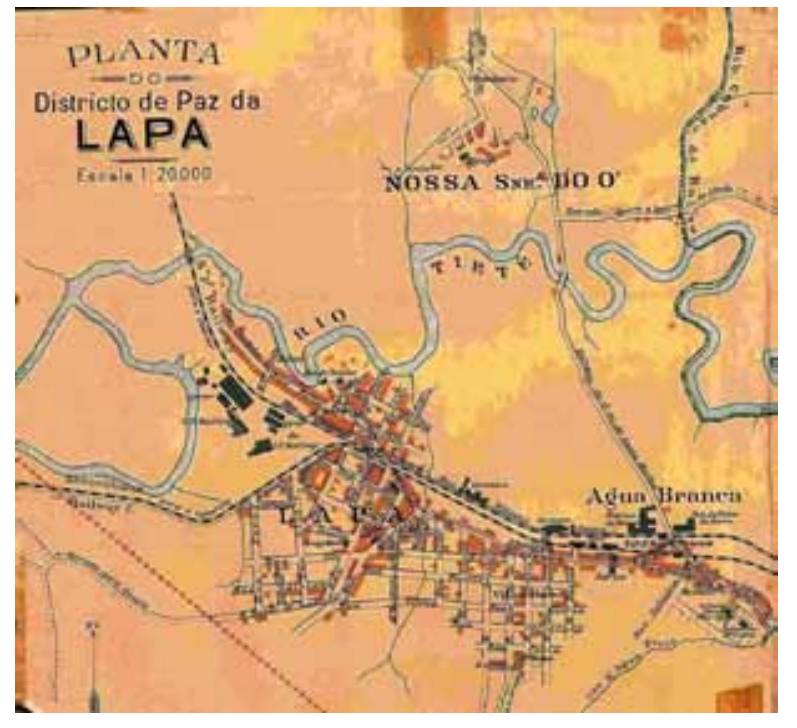

Figura 1: Ilustração: Mapa histórico da área em estudo de 1913. Fonte: Planta da cidade de São Paulo - eng. Civil Alexandre M. Cucuci e L. Fructuoso F. Costa -Companhia Lithographica Hartmann - Reichenbach de 1913.

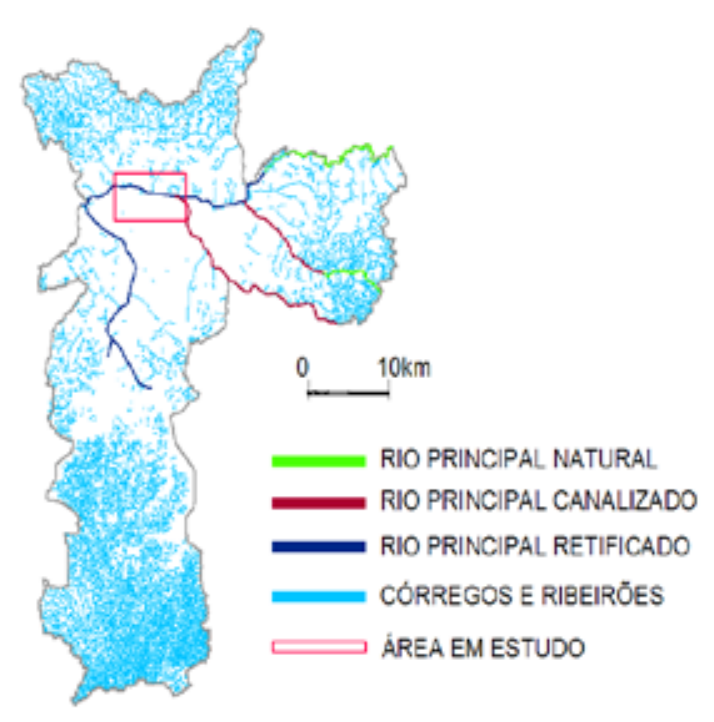

Figura 2: Ilustração: Mapa hidrográfico do município de São Paulo com a identificação da área de estudo. Fonte: Gegran

O rio Tietê compõe os principais Rios que atravessam o município de São Paulo, nasce a leste na serra do Mar e corre a oeste para o interior do continente onde se junta com o Rio Paraná até desaguar, mais ao sul do continente, no oceano Atlântico, como o Rio da Prata. Historicamente, o rio Tietê foi o responsável pela conquista do interior de São Paulo e do Brasil. Os caminhos terrestres e suas águas navegáveis, levaram os exploradores europeus a descobrirem novos lugares, serviu também como alimento, fornecendo água potável e diversos tipos de peixes para a província e para os viajantes. 
Até a metade do século $X X$ o rio Tietê cumpriu esplendidamente com seu potencial ambiental sustentável, proporcionando recreio, esporte e bom convívio social entre as pessoas com a natureza (fig. 3 e 4). Foi a partir de 1950, com o crescimento da expansão urbana não sustentável, que o rio e seus afluentes começaram a sofrer o processo de poluição e degradação de suas margens e de seu traçado natural, o que resultou em um ambiente hostil sem vida natural, sujeito à inundações e doenças, hoje cenário da cidade.
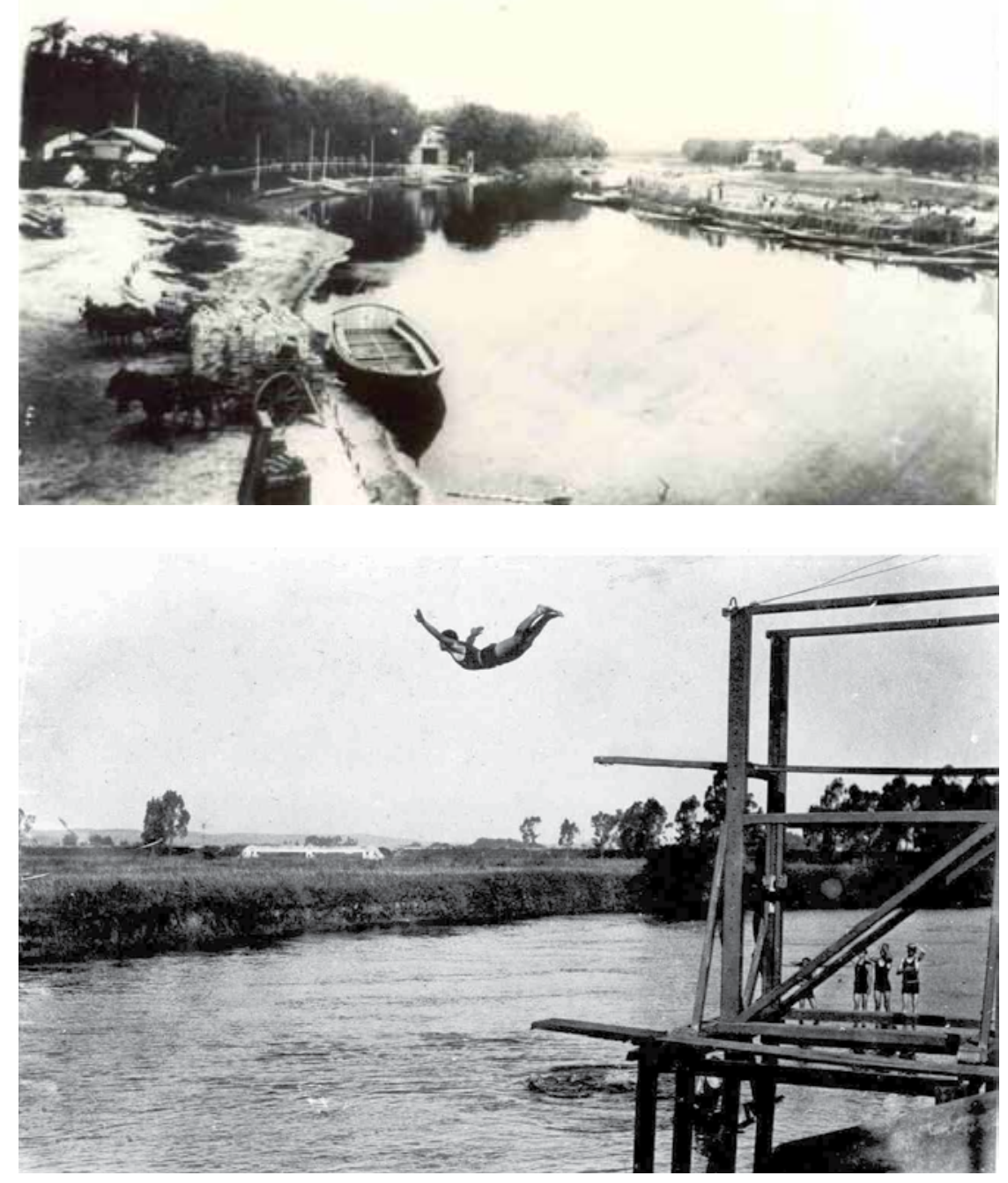

Figuras 3 e 4: llustrações: imagens históricas - Rio Tietê na cidade de São Paulo. Fonte: NÚCLEO UNIÃO PRÓ-TIETÊ. Fundação SOS Mata Atlântica - llustrações Beth Kok Desenvolvimento AR Gestão Ambiental Solução Estúdio Girassol - (http://www.arcplan.com.br/rededasaguas/nucleo/na_memoria.htm) 
O relevo que a natureza levou milhões de anos para formar, os terraços, as curvas sinuosas de toda a rede de pequenos rios, que compõe sua bacia, foram ocupados e modificados em curto espaço de tempo, pela ação do homem. A atuação sanitarista levou à impermeabilização do solo junto aos cursos d'água, canalização e retificação de quase todo o sistema que compõe o rio Tietê no trecho metropolitano da cidade de São Paulo. Na figura 1 pode-se verificar a região da Lapa em 1913, com os meandros naturais do rio Tietê, antes dele ser retificado.

O objetivo desta pesquisa é verificar as condições para a recuperação dos córregos da região da Barra Funda na cidade de São Paulo, a fim de aproveitar suas margens revitalizadas para a mobilidade sustentável. Esta pesquisa é importante para possibilitar o resgate do antigo bom convívio da cidade com a natureza. Hoje a ocupação urbana das margens dos rios e córregos da cidade gera inúmeros problemas ambientais e prejudica a cidade. Para que isso não ocorra, faz-se necessário um planejamento urbano, onde a gestão ambiental esteja inserida e atrelada a uma ação conjunta, com os diversos órgãos que atuam nestas bacias hidrográficas. O atual modelo de ocupação e uso dos cursos d'água, não será revertido em curto prazo, existem interesses econômicos que empurram a urbanização e, portanto, é necessário que ocorram intervenções nos três níveis de governo e profundas mudanças na sociedade, para que se crie condições para esta nova visão de mundo.

A metodologia utilizada para o desenvolvimento desta pesquisa foi a comparação entre mapas históricos e mapas atuais, pela sobreposição das imagens com desenho auxiliado por computador, através do programa AutoCAD. Foi realizado um levantamento fotográfico na visita ao local, pesquisa na literatura e nas fotos antigas para obtenção de dados e conceitos, e a digitalização em tela dos córregos e do sistema viário, sobre a imagem da cidade como pano de fundo.

\section{COMPREENSÃO E VISÃO DO TODO}

As ocupações urbanas das grandes metrópoles são formadas por extensas áreas pavimentadas, que impedem a respiração do solo, prejudicando a permeabilidade natural da terra, e inviabilizam a presença de vegetais. As espécies arbóreas não conseguem formar grupos para amenizar o calor nos dias quentes, e isto gera as "ilhas de calor" (fig. 5) que em alguns setores da cidade, chegam a ser insuportáveis, atingindo até 10 graus Celcius a mais que as áreas arborizadas (Lombardo, 1985). 


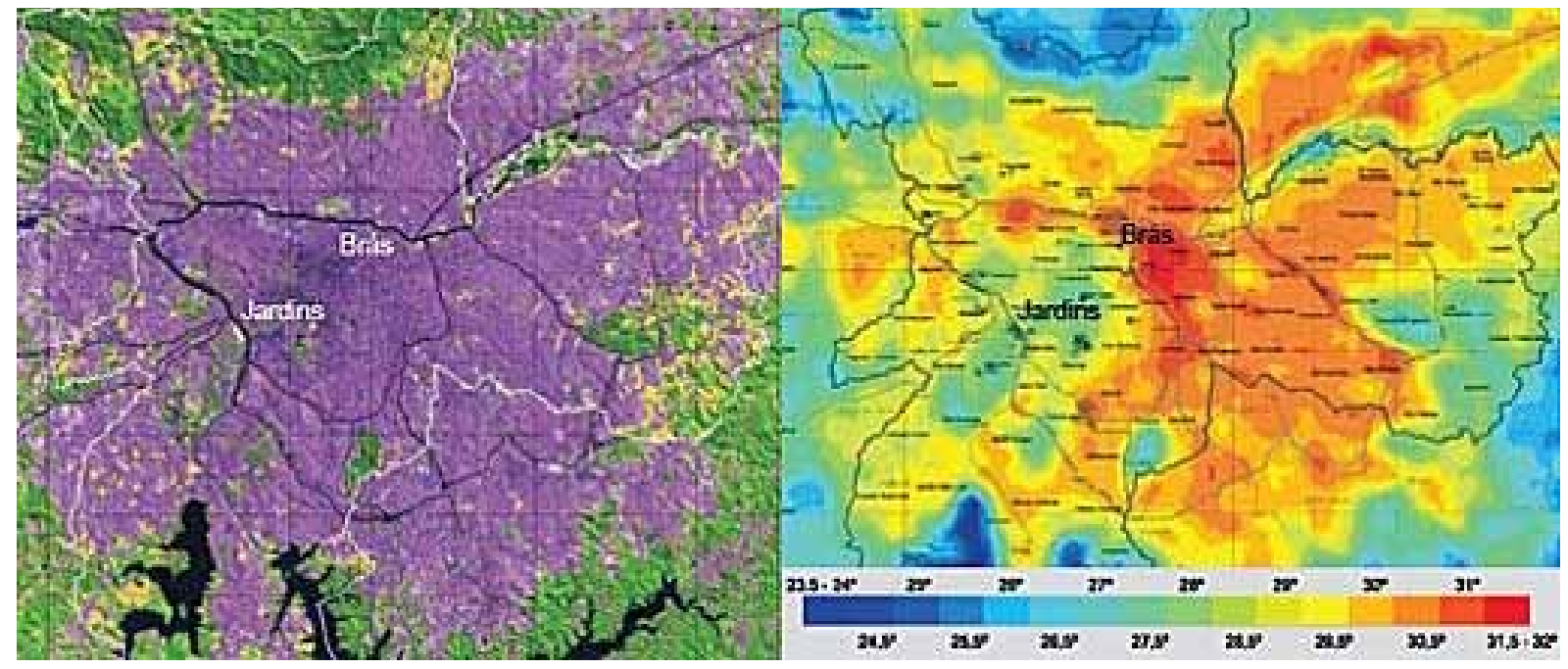

Figura 5: Áreas urbanizadas versus ilhas de calor em São Paulo. Fonte: http://institutocidadejardim.wordpress.com

A ocupação total da área de várzea dos rios e córregos leva a destruição dos recursos naturais, matas e antigos lagos da cidade, aumenta a poluição do ar, gera maior ruído e desconforto, e cria uma população doente. Hoje a metrópole vive no limite do suportável e ações que levam em consideração o respeito ao meio ambiente natural, passam a ser agora fundamentais para o urbanismo.

A poluição e descaracterização do local ocupado antigamente pelo rio, a destruição da fauna e flora, assim como a alteração de seu traçado original (fig. 6 e 7), aliado a ligação indiscriminada da rede de coleta de esgoto e pluvial ao seu leito, modificaram violentamente sua paisagem urbana colonial. Hoje, o desenho do Rio Tietê e córregos da região em nada lembram aquela época, em que a cidade ainda recebia a boa contribuição ambiental do Rio e seus habitantes podiam aproveitar este ecossistema natural, para a prática de esporte e lazer.

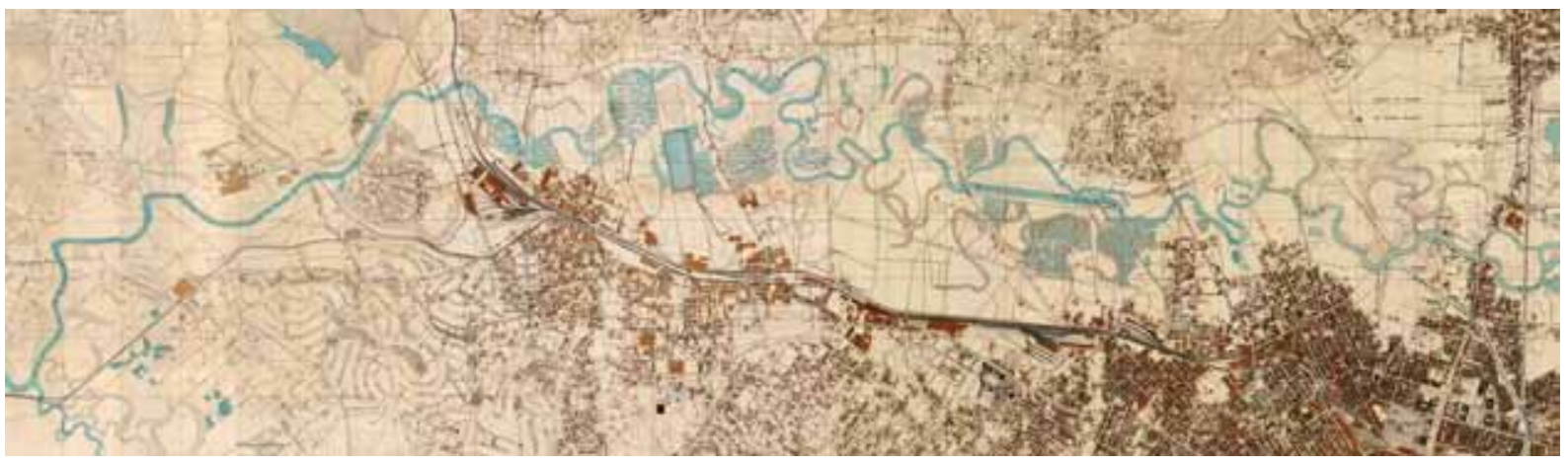

Figura 6: Mapa Topográfico do Município de São Paulo, executado pela empresa Sara Brasil, 1930 Publicado pela Prefeitura Municipal de São Paulo - traçado original do Rio Tietê. Trecho entre o Rio Tamanduateí ( à direita ) e o Rio Pinheiros ( à esquerda) 


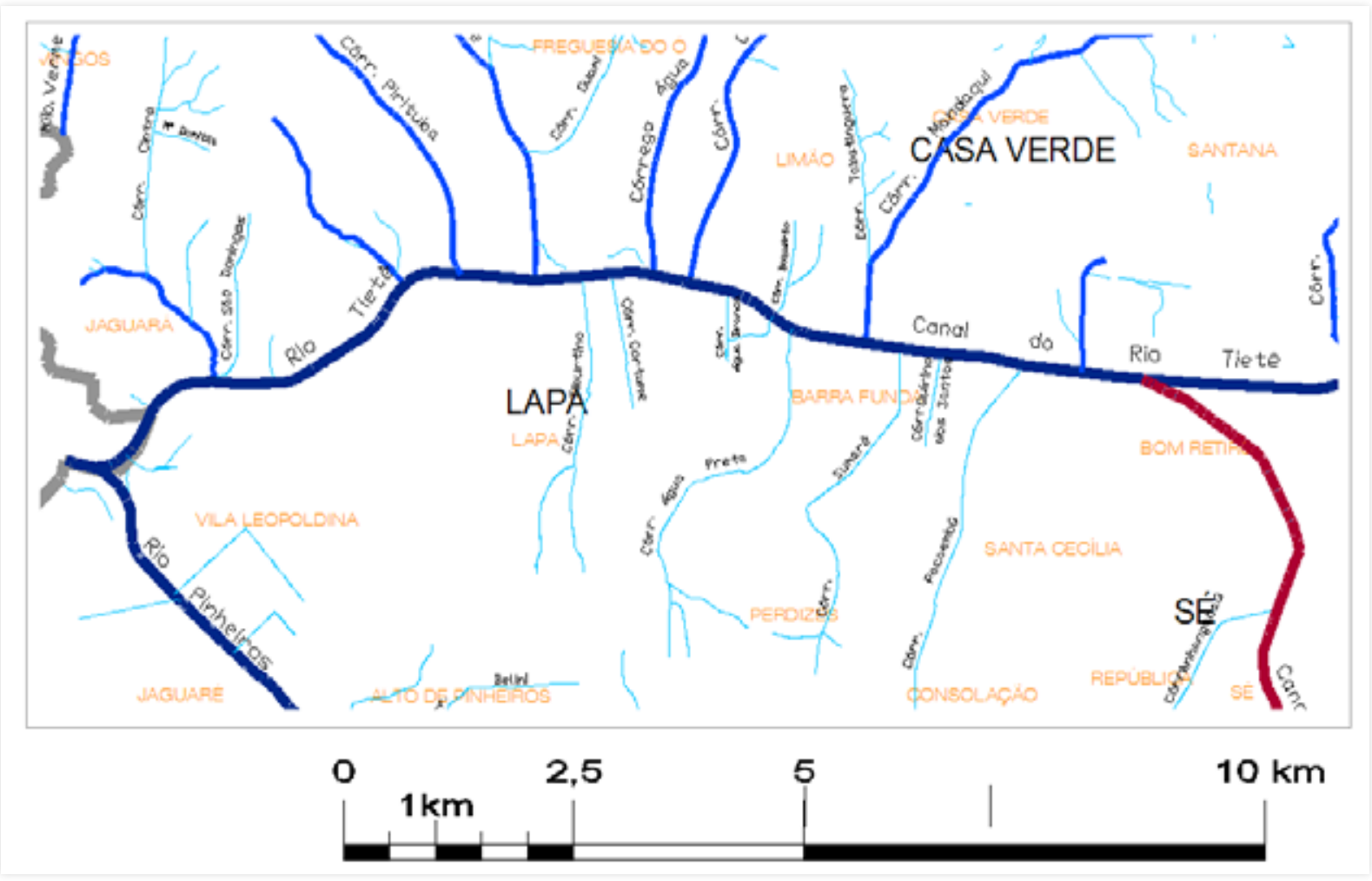

Figura 7: Ilustração: Mapa hidrográfico de São Paulo - Rio Tietê retificado - Trecho entre o Rio Tamanduateí ( à direita em vermelho ) e Rio Pinheiros ( à esquerda). Fonte: Gegran

A recuperação dos córregos da região da Barra Funda, servirá para fazer a conexão com mobilidade sustentável entre a Av. Marginal do rio Tietê e o bairro, através de caminhada e do uso de bicicleta, e transpor a ferrovia, ou integrá-la também como futura área verde. Este caminho proporcionará a ligação com o Parque da Água Branca, passando pelo terminal intermodal Barra Funda e o Memorial da América Latina, criando um corredor verde, somente para pedestres e ciclistas, formando uma rede sustentável entre estes dois pólos e a cidade. A hipótese de transformar o espaço ocupado pela ferrovia em uma grande área verde, é uma tendência mundial que vem ganhando força, devido à necessidade da implementação de sustentabilidade urbana nas cidades.

\section{CARACTERIZAÇÃO DA ÁREA DE ESTUDO}

Os córregos do Cortume, Água Branca, Água Preta, Sumaré, Quirino dos Santos e Pacaembú, fazem parte de um conjunto de micro-bacias, que compõe a região da Barra Funda (fig. 8). As micro-bacias denominadas: Água Branca, Quirino dos Santos 
e Pacaembú, são afluentes da margem esquerda do rio Tietê, as quais ainda possuem um trecho não canalizado, e são portanto nosso objeto de estudo.

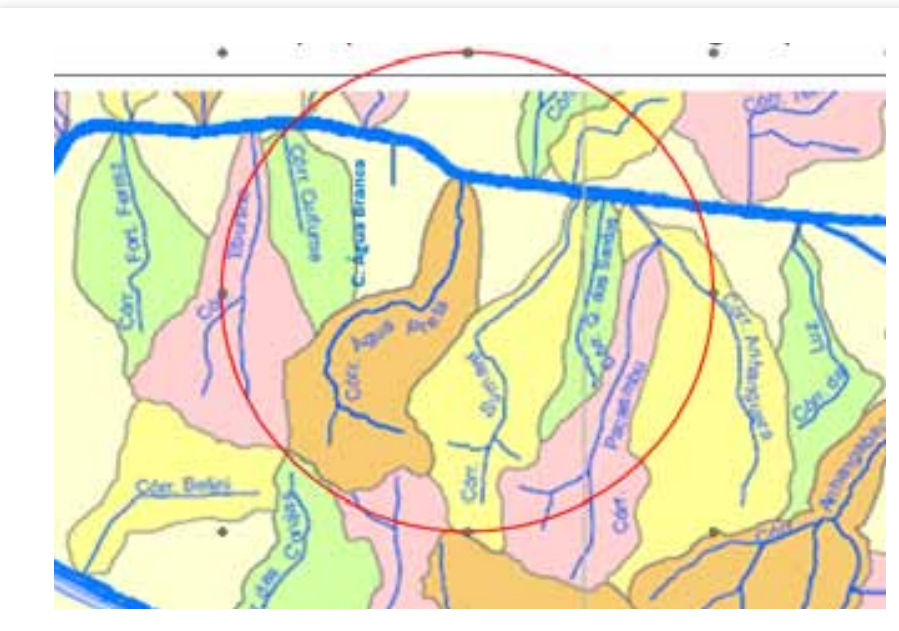

Da esquerda para a direita:

- Córrego do Cortume

- Córrego Água Branca

- Córrego Água Preta

- Córrego Sumaré

- Córrego Quirino dos Santos

- Córrego Pacaembú

Figura 8: Ilustração: Área em estudo - Mapa da região da Barra Funda com o desenho das pequenas bacias dos córregos que abastecem o rio principal: Tietê. Fonte: Detalhe do Mapa Hidrográfico do Município de São Paulo com divisão de bacias - Fundação Centro Tecnológico de Hidráulica, 2012 * modificado pelos autores: acréscimo do córrego Água Branca

\section{Córrego Quirino de Santos}

O córrego Quirino dos Santos pertence a uma destas micro-bacias que existem na área em estudo, que servem como drenagem natural para a cidade no sentido sul norte. Este córrego está retificado e segue canalizado por baixo da Rua Quirino dos Santos, atravessando a Av. Marquês de São Vicente. A partir do cruzamento destas duas ruas mencionadas ele se torna um canal retificado a céu aberto (foto 1) que passa por dentro de antigo parque de diversões e deságua no rio Tietê entre as pontes do Limão e da Casa Verde. O trecho em canal aberto encontra-se bastante degradado sem, praticamente, nenhuma vegetação ciliar (foto2).

O trecho que atravessa o parque de diversões, embora poluído, está arborizado e apresenta vegetação ao longo do córrego. Uma via não pavimentada surge no trecho fora do terreno do parque de diversões e acompanha o córrego, que neste local encontra-se mais devastado, possuindo apenas algumas árvores espalhadas, entulho e lixo ao longo do percurso até desaparecer na Av. Marquês de São Vicente. Próximo a Av. Marquês de São Vicente, observa-se a presença de algumas espécies de Fícus e Bananeira. Estas espécies arbóreas atraem a avifauna, mas o predomínio maior é das gramíneas. 


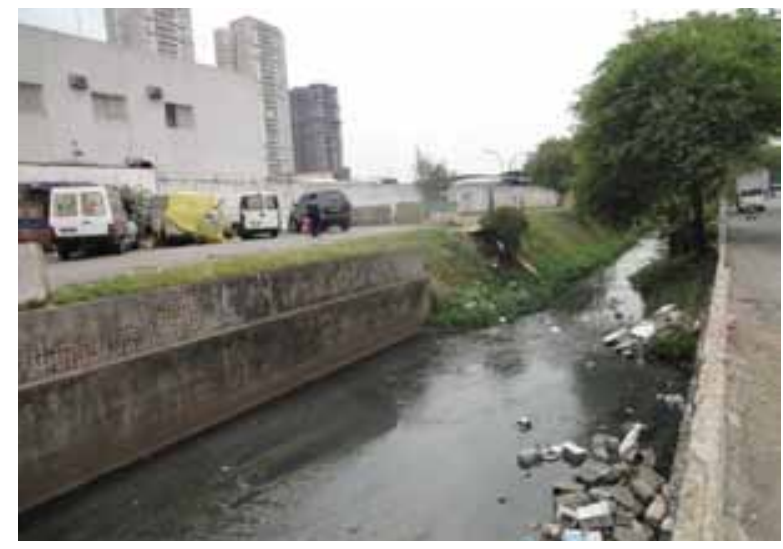

Foto 1: córrego Quirino dos Santos: início do trecho do canal aberto - presença de entulho.

Fonte: dos autores

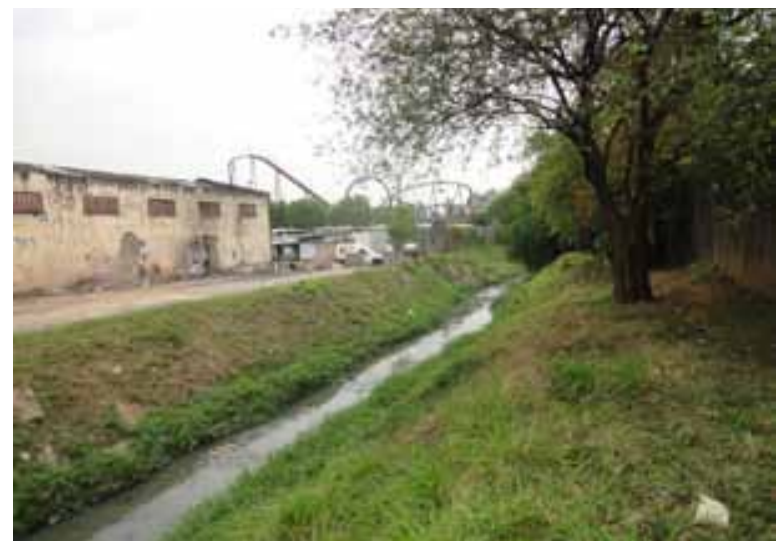

Foto 2: córrego Quirino dos Santos: trecho próximo ao antigo parque de diversões.

Fonte: dos autores

\section{Córrego Pacaembu}

O córrego Pacaembu encontra-se no limite leste da área destinada à Operação Urbana Água Branca. Na área de estudo, o mesmo segue pela Av. Doutor Abraão Ribeiro, sentido norte, até desaguar no rio Tietê. Após o trecho canalizado por via subterrânea, no cruzamento entre a Avenida Abraão Ribeiro e Rua Padre Luis Alves de Siqueira, o córrego corre a céu aberto (foto 3). Segundo o Estudo de Impacto Ambiental feito para a Operação Urbana Água Branca, muitas espécies registradas nesta área têm grande potencial para atração de aves (foto 4), como a embaúba, aroeira-pimenta, e as frutíferas amoreiras, pitangueira e goiabeira. Por outro lado, observou-se a presença de entulho e principalmente sacolas plásticas no trecho aberto.

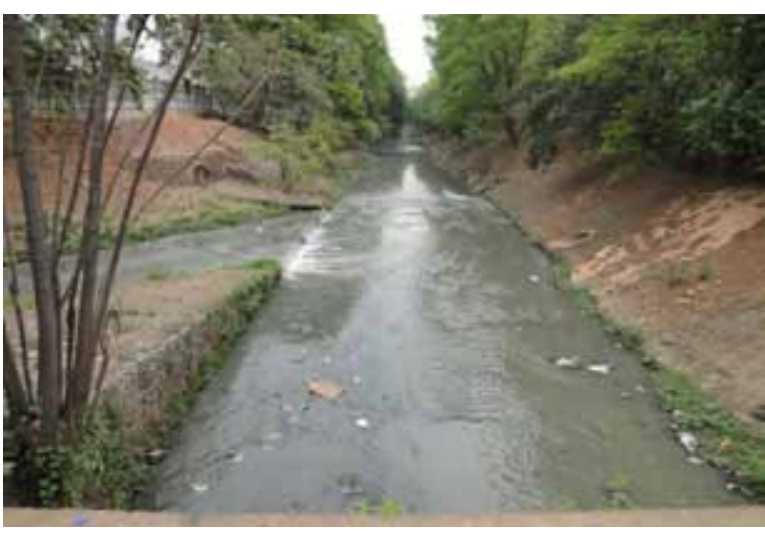

Foto 3: córrego Pacaembu: início do trecho do canal aberto - presença de entulho *(recebe as águas do córrego anhanguera). Fonte: dos autores

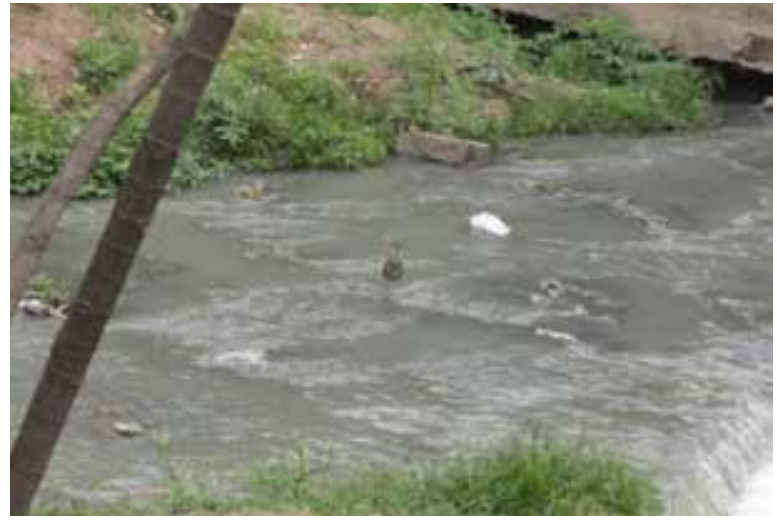

Foto 4: córrego Pacaembu: presença de aves no local. Fonte: dos autores 


\section{Córrego Água Branca}

O córrego Água Branca se desenvolve em direção ao rio Tietê paralelo à Rua Professor José Nelo Lorenzon, passando pelo estabelecimento comercial Telha Norte que fica na marginal do Rio Tietê. Este córrego passa por dentro da favela do Sapo, a qual contribui para a degradação ambiental através da ocupação desordenada e do lançamento direto no córrego de vários resíduos de lixo (foto 5). Após o trecho canalizado por via subterrânea, onde corre a céu aberto, observa-se a ausência praticamente total de vegetação ciliar arbórea. Não se encontra no local, espécies atraentes para a avifauna. Assim como os outros corpos d'água mencionados anteriormente, o córrego da Água Branca apresenta-se visivelmente degradado (foto 6).

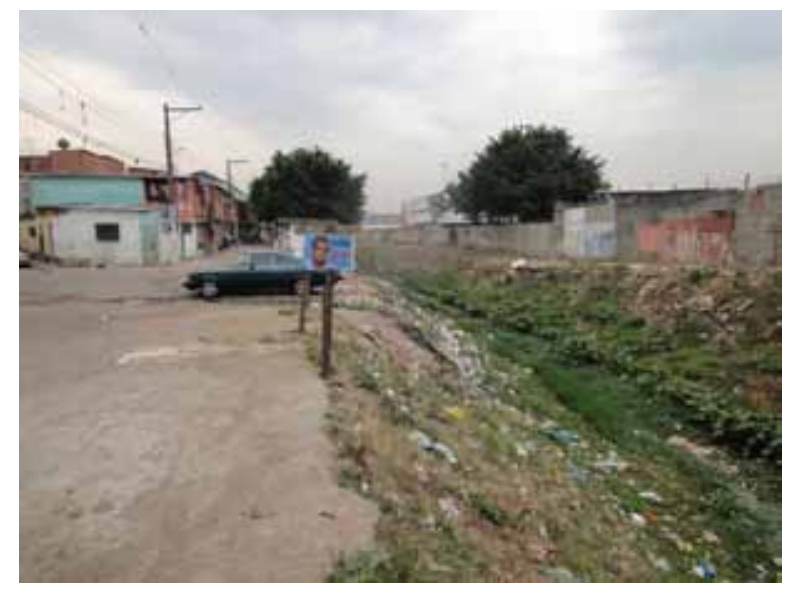

Foto 5: córrego Água Branca: ao lado da favela do Sapo, presença de muito lixo e entulho.

Fonte: dos autores

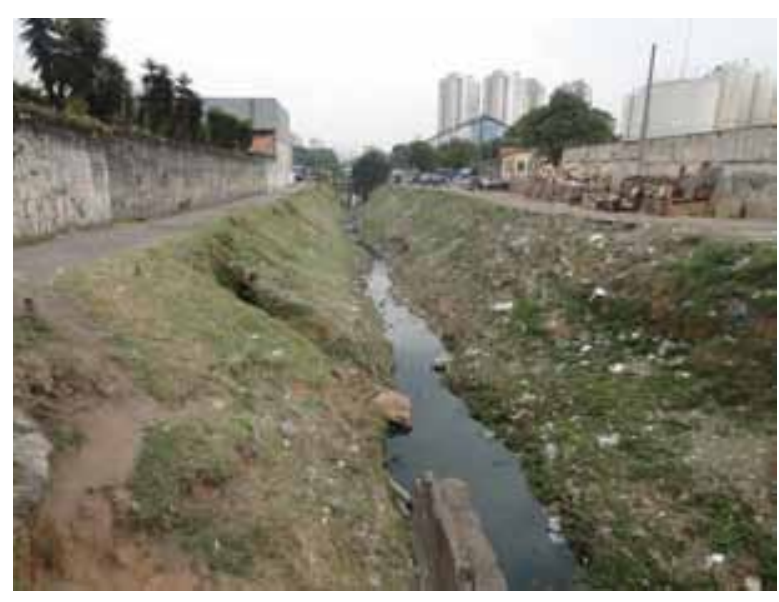

Foto 6: córrego Água Branca: trecho próximo á Marginal do Rio Tietê, sentido Sul.

Fonte: dos autores

Devido aos lançamentos de esgotos sanitários, tanto doméstico como industrial, acima das respectivas capacidades, estes cursos d'água estão em condições ambientais muito precárias, e na área em que estes córregos se encontram, existe uma carência de linhas de drenagem. Esta é uma das principais causas das constantes inundações nesta região no período de chuvas.

Os córregos estão inseridos em uma zona muito urbanizada, que durante a sua história sofreram alterações nas características de seus cursos naturais como retificações, canalizações e se tornaram receptores dos diversos tipos de detritos que alteram a qualidade das águas e provocam o seu assoreamento.

Como a planície aluvial do rio Tietê é formada por extensas áreas de várzea e brejo, 
frequentemente são feitos aterramentos, favorecendo as erosões urbanas e reduções de várzeas tornando os cursos d'água locais mais suscetíveis aos assoreamentos.

A recuperação e integração do rio Tietê e seus cursos d'água com a cidade de São Paulo é importante também para a implantação do sistema de drenagem, com áreas verdes permeáveis, a fim de proporcionar melhores condições ambientais. Para isso um Plano de Desassoreamento e limpeza periódica das galerias dos córregos já estão sendo feitos pela Prefeitura Municipal de São Paulo. A Operação Urbana Água Branca do município de São Paulo tem como objetivo principal, diminuir os problemas relacionados às inundações.

\section{A MOBILIDADE SUSTENTÁVEL E A INFRAESTRUTURA VERDE}

A sustentabilidade para a mobilidade urbana é: "a capacidade de fazer as viagens necessárias para realização dos direitos dos cidadãos com o menor gasto de energia possível e menor impacto ao meio ambiente." (Ministério das cidades, 2007ª). A condicionante necessidade de deslocamento e a crise em que se encontra o atual modelo de transporte individual por automóveis, para o qual não há mais espaço nas cidades, indicam a necessidade de se criar novos corredores urbanos, para o pedestre e o ciclista, para garantir a circulação urbana visando a melhoria da qualidade de vida das pessoas em relação à saúde física e mental. A boa mobilidade aumenta o acesso a serviços essenciais e também aos serviços que tornam a vida mais agradável, dando mais opções sobre onde queremos viver e o estilo de vida que queremos ter.

Torna-se cada vez maior a necessidade da limitação das viagens motorizadas nas cidades. Para isso é preciso aproximar os locais de moradia dos locais de trabalho, o acesso aos serviços essenciais, ou ampliar o modo coletivo e os meios não motorizados de transporte. O principal objetivo da mobilidade sustentável é a redução dos impactos ambientais e sociais da mobilidade motorizada existente.

A inclusão dos meios não motorizados nos deslocamentos urbanos deve ser abordada como complemento do conceito de Mobilidade Urbana para cidades sustentáveis como forma de inclusão social, de redução e eliminação de agentes poluentes e meIhoria da saúde da população. Conforme caderno de referência PlanMob do Ministério das cidades, 2007b: 
"A integração da bicicleta nos atuais sistemas de circulação é possível, mas ela deve ser considerada como elemento integrante de um novo desenho urbano, que contemple a implantação de infra-estruturas, bem como novas reflexões sobre o uso e a ocupação do solo urbano"

Para a área em estudo, existe um Plano Cicloviário feito para o bairro da Lapa. Esse plano da Subprefeitura da Lapa foi apresentado à população em 26 de abril de 2012 e está em processo de aprovação junto ao CET (Companhia de engenharia de tráfego) e a Secretaria Municipal de Transportes. O plano foi desenvolvido pela Ativa - Engenharia, Arquitetura e Urbanismo e custeado pela Secretaria do Verde e Meio Ambiente (fig. 9).

Segundo a Ciclocidade (Associação dos Ciclistas Urbanos de São Paulo), o plano prevê a construção de ciclovias, ciclofaixas e trânsito compartilhado com sinalização - conhecida também como ciclorrota - e instalação de paraciclos. Ao todo seriam 100 km de estrutura construída, dividida em três momentos: o primeiro de reformas mais simples (38 km de ciclofaixas e ciclorrotas), em até 2 anos; o segundo, com $27 \mathrm{~km}$, prevê obras pequenas e sinalização, já incluindo ciclovias; o terceiro, com 35 km e obras de maior porte, deve demorar até 10 anos para estar concluído. O plano também propõe a ligação da infraestrutura cicloviária às estações de trem e de metrô da região e considera locais de maior interesse, como igrejas, comércio e faculdades, e as vias em que, segundo o estudo, circulam mais ciclistas.

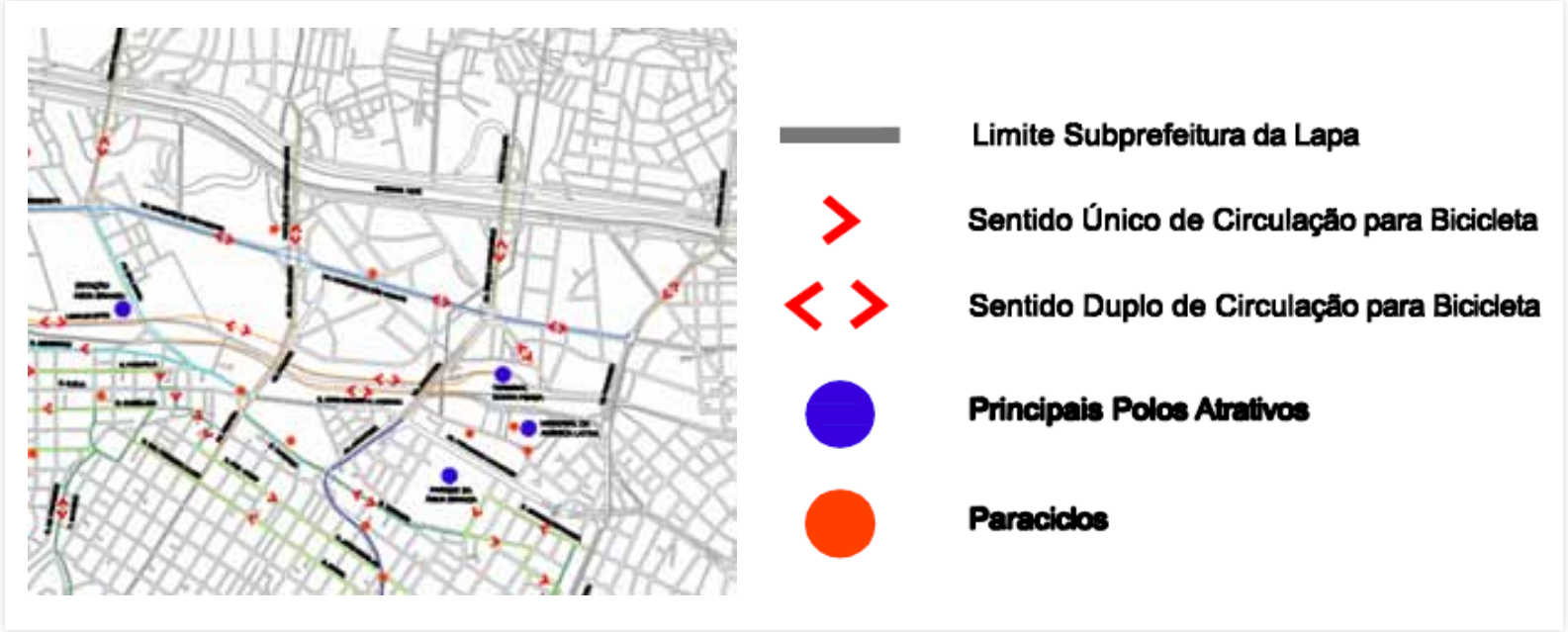

Figura 9: Ilustração: Planta geral do Plano Cicloviário da Subprefeitura da Lapa. Fonte: Ativa Engenharia, Arquitetura e Urbanismo - custeado pela Secretaria do Verde e Meio Ambiente do Município de São Paulo. 
Para que haja esta mobilidade sustentável, faz-se necessário incorporar nesta rota do plano cicloviário, a região dos córregos Água Branca, Quirino dos Santos e Pacaembu, que deverão ser recuperados. Os parques lineares destes córregos contribuirão para o bem estar e qualidade de vida das pessoas da região e para a acessibilidade entre as áreas verdes e os outros locais de interesse.

\section{ESTUDOS DE CASO DE REVITALIZAÇÃO DE CÓRREGOS E RIOS URBANOS}

Na Córeia do sul, em Seul, o córrego Cheong Gye Cheon hoje é um modelo de revitalização (foto 7 e 8). Ele foi totalmente despoluído e as vias e o viaduto que cobriam este canal urbano foram demolidos e apagados da paisagem da cidade.

Segundo informações do site Rede Nossa São Paulo e o Sr. In-Heun Lee que coordenou o projeto de recuperação:

“...do começo ao fim, o projeto custou US\$ 380 milhões. Houve uma redução da temperatura de 3,6 graus na área, queda de $38 \%$ nas emissões de poluentes, valorização dos imóveis no entorno e um aumento de 4 para 25 espécies de peixes e de 6 para 36 espécies de aves."

Os resultados mostraram que estes investimentos asseguraram a melhoria da qualidade de vida dos cidadãos a partir da paisagem restaurada. (http://www.nossasaopaulo.org.br).
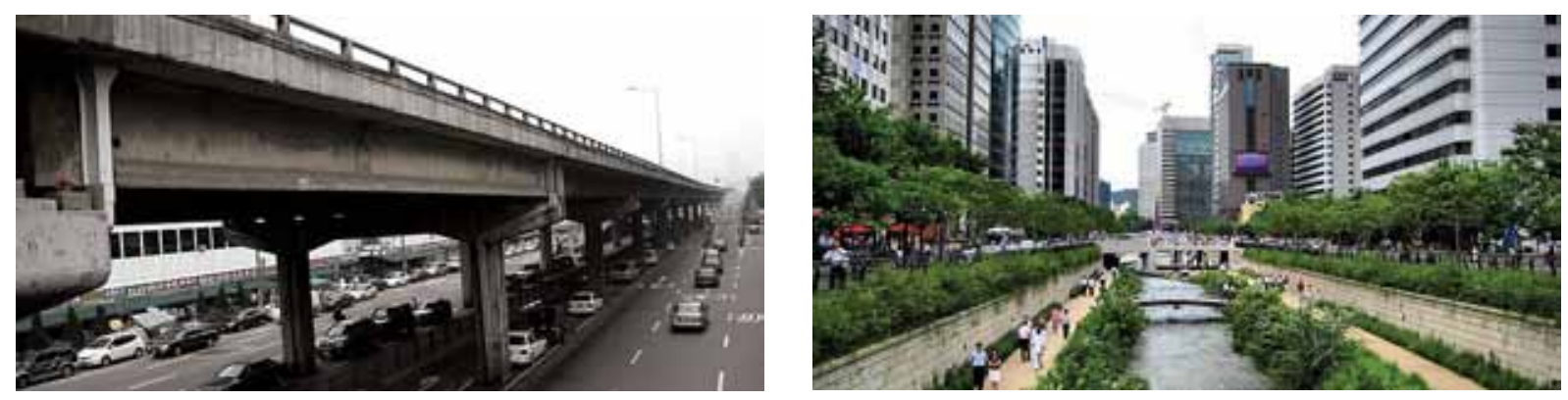

Foto 7: Córrego Cheong gye cheon, em Seul, na Coréia do Sul antes da demolição do viaduto que cobria o canal. Fonte: Instituto SOS Rios do Brasil - http://sosriosdobrasil.blogspot.com.br

$\mathrm{Na}$ China, o distrito de Liwan, a oeste das antigas muralhas da cidade de Guangzhou, foi no passado um bairro tranquilo, com muitos canais, lagos e ruas estreitas. $O$ canal Lizhiwan (foto 9 e 10) ligava o Rio das Pérolas, aos jardins imperiais de Liwan. Com o passar do tempo devido ao processo de urbanização da cidade, o canal Lizhiwan foi 
coberto, transformando-se na estrada Xiguanguwan e em uma vala para drenagem de esgotos (http://mobilidadesustentavel.blog.uol.com.br). Segundo Lincoln Paiva, do site Mobilidade Sustentável:

"na década de 1990, Guangzhou começou a restaurar todo o sistema hidrológico no Distrito Liwan. Com a construção ocorrendo principalmente durante 2009-2010, foram restaurados 121 segmentos do rio e sistema de canal começou incluindo o canal Lizhiwan. Os esgotos foram conectados a tubulações novas, o canal foi dragado e descontaminados, as paredes do canal foi reconstituída e a terra ao longo do canal foi limpo, adicionando novas passarelas e um novo paisagismo. O canal foi ligado novamente ao Lago Liwan para permitir a água circulação dos canais. Em 2009, o distrito Liwan criou um novo distrito de 58 hectares que ficou conhecido como a Lizhiwan cultural, numa área circundante para preservar e restaurar muitos dos edifícios históricos ao redor que viraram museus."
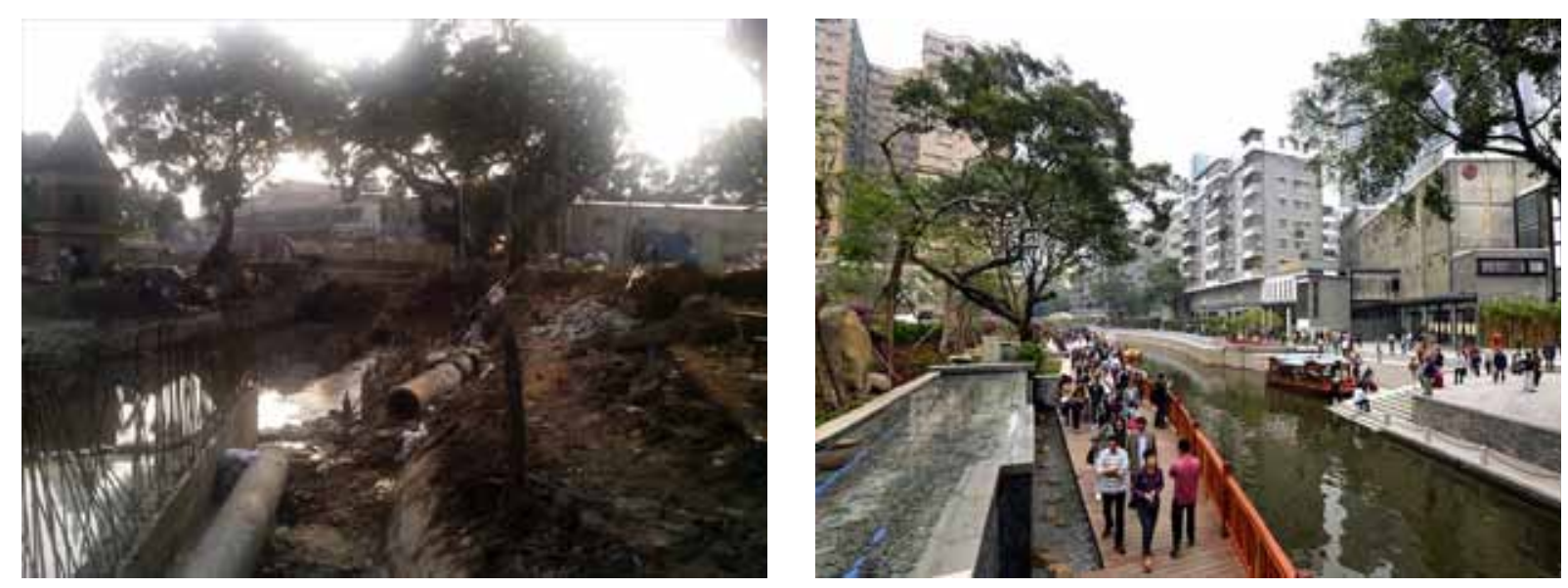

Foto 9: Canal Lizhiwan- China: as obras e o desenvolvimento das hidrovias.

Fonte: ITDP / http://mobilidadesustentavel.blog.uol.com.br

No Brasil, estado de São Paulo, Município de Sorocaba a prefeitura tem se destacado pelos seus trabalhos de ações integradas no projeto de recuperação e revitalização do Rio Sorocaba e de córregos urbanos. Os trabalhos envolvem, além do tratamento de esgotos domésticos, a construção de bacias de contenção, recuperação das margens e de áreas degradadas, construção de conjuntos habitacionais para famílias que vivem em áreas de risco, ciclovias e parques integrados (fotos 11 e 12). 

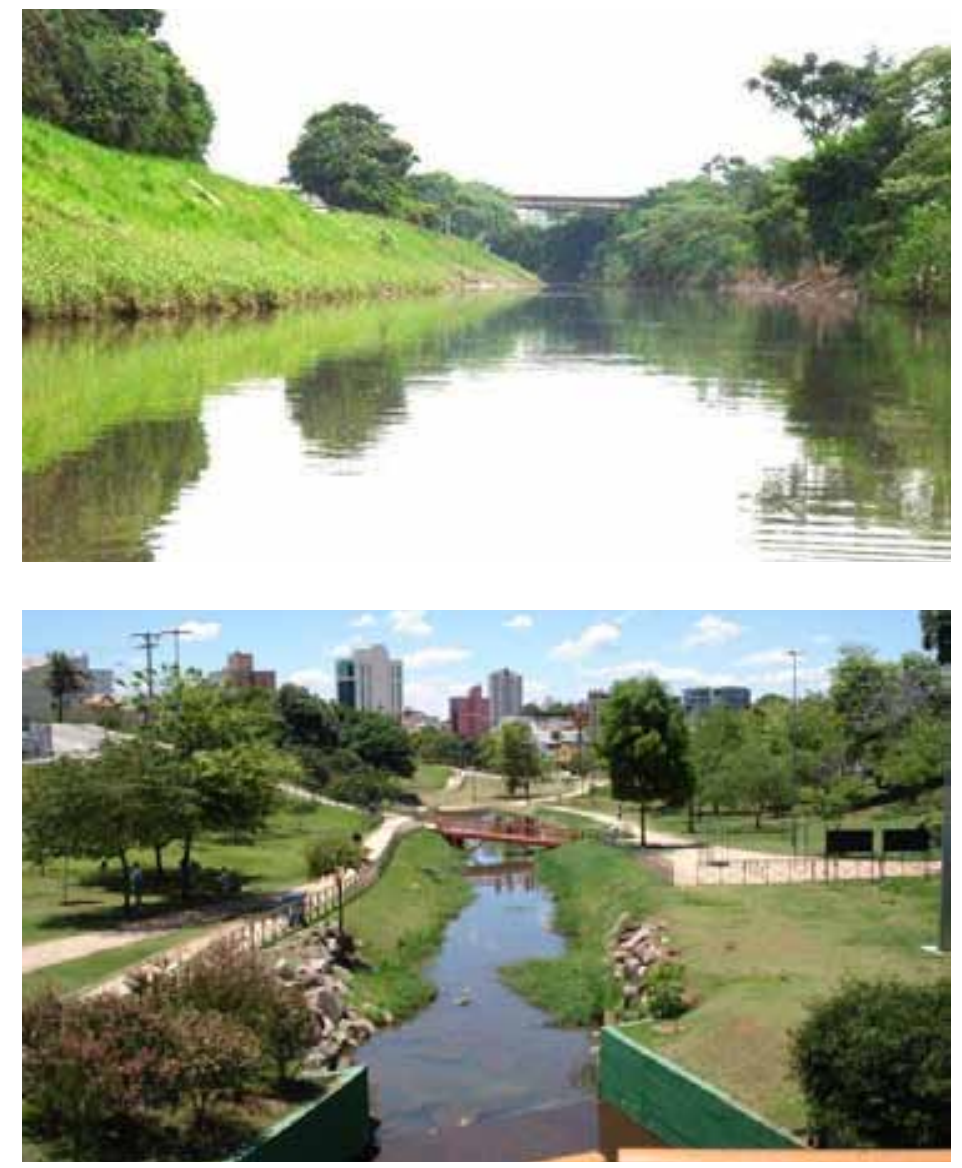

Foto 11: Rio Sorocaba: longo trabalho para a despoluição das águas. Fonte: SAAE-Sorocaba - Serviço Autônomo de Água e Esgoto de Sorocaba

Foto 12: Rio Sorocaba: revitalização e integração com parques e ciclovias. Fonte: Associação Nacional dos Órgãos Municipais de Meio Ambiente

Também no Brasil, estado de São Paulo e Município de São Paulo, o Córrego Pirarungáua, passou por um processo de revitalização (fotos 13 e 14). Esse córrego é um dos formadores do Riacho do Ipiranga e sua nascente encontra-se dentro dos limites do Jardim Botânico, que faz parte do Parque Estadual das Fontes do Ipiranga.

O córrego corria por um canal subterrâneo construído em 1940, sem muita tecnologia, com paredes de tijolo e uma laje. Como um trecho da Alameda Fernando Costa, que cobria o córrego, cedeu e os técnicos constataram que o local estava condenado por inteiro, do ponto de vista estrutural, a revitalização tornou-se possível. O calçamento existente foi retirado e a recuperação das margens do Pirarungáua foi iniciada, permitindo que o córrego voltasse a correr a céu aberto.

O paisagismo das margens do córrego foi regenerado, com a utilização de espécies da Mata Atlântica, retiradas dos locais onde estão as obras do trecho sul do Rodoanel de São Paulo. O corredor de entrada foi adaptado para permitir a acessibilidade de pessoas com dificuldade de locomoção. O projeto é do arquiteto Paulo Ganzelli (http://www.ambiente.sp.gov.br). 


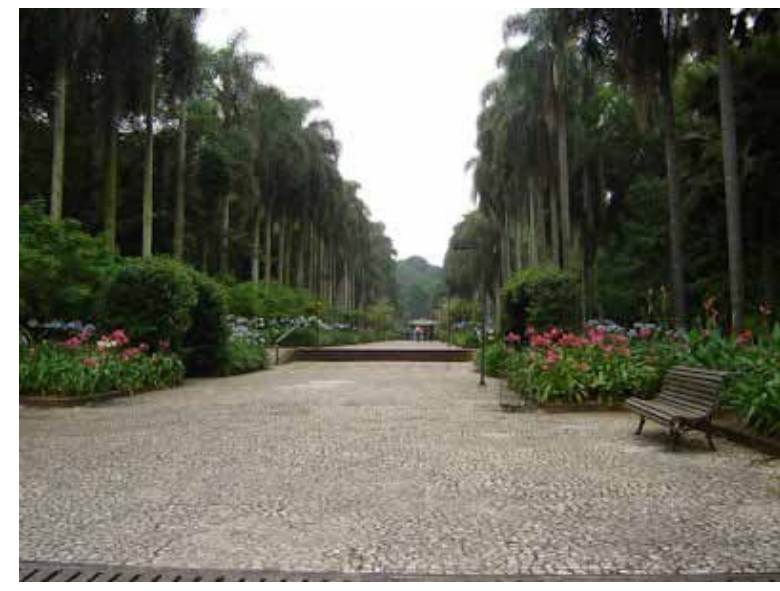

Foto 13: Córrego Pirarungáua: no canal subterrâneo, antes da retirada do calçamento.

Fonte: ONG Vira Mundo

( http://saopaulo-sp-aac.blogspot.com.br/)

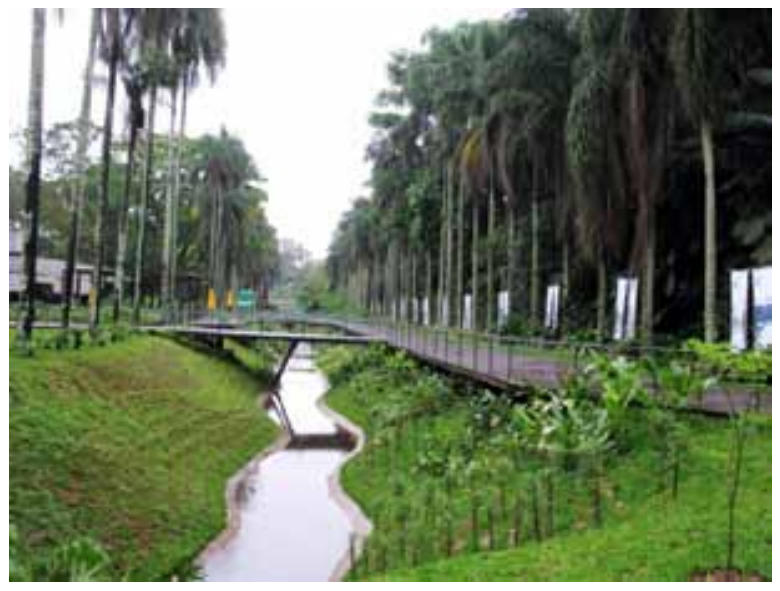

Foto 14: Córrego Pirarungáua: integrado a decks e passarelas na entrada do Jardim Botânico. Fonte: Portas de Interlagos

(http://www.portaldeinterlagos.com.br)

\section{DIRETRIZES GERAIS DA RECUPERAÇÃO DOS CÓRREGOS E NATURALI- ZAÇÃO DA MALHA URBANA}

No estudo realizado, pode-se constatar que os córregos descritos na região da Barra Funda, sofreram grandes alterações em seus traçados originais. $O$ relevo da região foi modificado através de aterramentos, os córregos foram canalizados, a vegetação e a permeabilidade da área diminuíram, a temperatura ambiente aumentou e as enchentes são frequentes neste local. Trata-se da ocupação urbana de uma área de várzea de rio, cujo solo é frágil, formado por um complexo sistema de drenagem natural, desenhado pela natureza durante milhões de anos, que passou a ser modificado por ação antrópica de maneira predatória. Os estudos apontam que no passado, houve um momento em que a bacia hidrográfica convivia em harmonia com a cidade e seus habitantes, diferentemente do que ocorre hoje. O que se percebe é um ambiente hostil, desumano totalmente descaracterizado.

A recuperação dos córregos da região da Barra Funda na cidade de São Paulo, e o aproveitamento de suas margens revitalizadas para a mobilidade sustentável, servirão para melhorar a qualidade de vida dos habitantes, através da conexão do Parque da Água Branca e ampliação das áreas verdes com vias públicas mais confortáveis, eficientes e ecológicas.

Para garantir uma melhora significativa na qualidade de vida da população e resgate 
do antigo convívio social com a natureza, o ambiente urbano precisa oferecer áreas verdes interligadas umas as outras, ligadas à malha urbana, com meio de transporte sem o uso de veículos motorizados e poluentes. As vias de pedestre serão os capilares da rede de transporte sustentável e deverão ser implantadas a nível local, para percorrer pequenas distâncias nos bairros (residências, serviços e comércio) e formar conexões com os córregos revitalizados e as áreas de lazer.
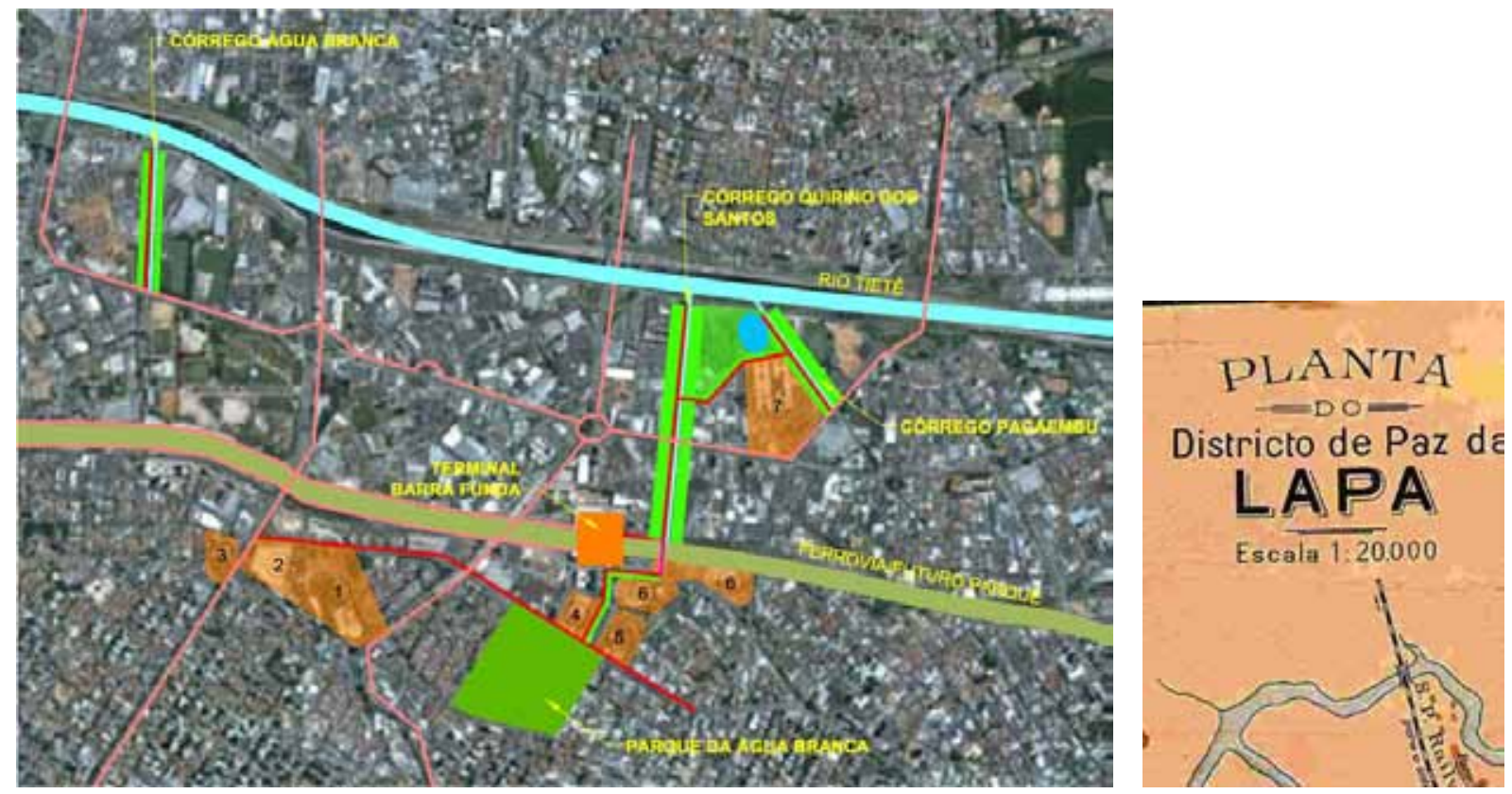

Figura 16: Ilustração: Área em estudo. Fonte: Desenho dos autores sobre imagem do site Google.

É preciso criar vias de pedestre e ciclovias, com infraestrutura verde, que façam a ligação entre os parques lineares dos córregos revitalizados e o Parque da Água Branca, passando pela linha férrea, a qual divide o bairro ao meio. A integração de áreas divididas por rodovia e/ou linha férrea é um desafio antigo para quem trabalha com planejamento urbano. $\mathrm{O}$ espaço hoje ocupado pela ferrovia será considerado como o futuro Parque Linear Brás-Lapa, que é uma proposta da disciplina Projeto Sustentável da Pós-Graduação da Universidade de São Paulo, onde a ferrovia deverá ser rebaixada em alguns trechos para que a área superficial seja aproveitada como Parque Linear conforme os princípios da mobilidade sustentável. Esta área poderá integrar nossa proposta, ampliando assim a rede de infraestrutura verde na região.

A via de pedestre e ciclovia proposta precisará ter um trecho elevado, para transpor a linha férrea que neste setor permanecerá na superfície, devido à proximidade com 
o terminal intermodal Barra Funda. Desta maneira será possível estabelecer a conexão direta das ciclovias, calçadas da região e dos córregos a serem recuperados: Água Branca, Quirino dos Santos e Pacaembú, com o Terminal Barra Funda, inclusive com serviço de apoio ao usuário através da construção de um bicicletário neste local. Conforme analisado no mapa, há outros pontos de interesse e áreas verdes na Barra Funda, que poderiam ser melhor utilizados pela população. O Fórum Criminal, situado entre a Av. Dr. Abraão Ribeiro e a Av. Marginal Tietê, reserva em bom espaço para revitalização na malha urbana; ali existe espaço para a criação de um lago, que poderá servir para o controle das águas, e para tornar o ambiente mais fresco e agradável.

Do outro lado da linha férrea, a linha de pedestres elevada deverá descer até o nível do Memorial da América Latina de onde seguirá em nível até o Parque da Água Branca, com jardins, ciclovia e pista de caminhada, proporcionando a integração deste importante parque cultural com as pessoas da cidade (inclusão social). Segundo análise dos mapas da região, no local onde hoje está implantado o Memorial da América Latina, havia um córrego, provavelmente o atual Córrego Quirino dos Santos, é preciso que haja a descanalização deste trecho do córrego e a localização e revitalização de sua nascente. A intenção é mostrar sua importância como patrimônio natural e trazer de volta sua singela contribuição ao meio ambiente.

Este sistema aéreo para pedestres precisará conter elevador, esteira rolante e escada comum, para permitir a passagem livre e mecanizada do usuário com bicicleta, cadeira de rodas, carrinhos de bebê e de carga, a fim de permitir acessibilidade a todas as pessoas.

Os estudos demonstram que há a necessidade de integração do Memorial da América Latina com o Parque da Água Branca através de infraestrutura verde, que neste percurso é quase inexistente. Esta integração proporcionará a conexão da população do bairro dividido pela linha férrea, com mobilidade urbana sustentável, oferecendo lazer, esporte e sociabilidade, para trazer melhor qualidade de vida, e contribuir com uma nova visão de mundo para as cidades. Faz-se necessário também a integração deste setor, com as ações da Operação Urbana Água Branca, e a ligação com a cidade através do futuro parque linear, ao longo do trilho do trem, Brás - Lapa. Esse parque servirá para levar as pessoas para outros parques e equipamentos culturais mais distantes, através da linha férrea subterrânea e da rede de metrô.

A pesquisa nos leva a concluir que, os córregos precisam de novas propostas de uso, com uma faixa de proteção ambiental maior, para de fato atender as questões 
de lazer, valorização dos pedestres e ciclistas, e assim recriar um ambiente mais natural, abandonado pela cidade nestes últimos anos. Para aumentar as áreas verdes, o município poderá usar o instrumento legal do Direito de Preempção, onde poderá delimitar as áreas em lei específica e, nos cinco anos seguintes terá a preferência para adquirir imóvel urbano em razão das diretrizes da política urbana. Segundo estudo dos arquitetos da SWA, o ideal para as margens dos córregos, seria a instalação de um sistema de gabião contínuo, reparação da vegetação e a construção de novo declive com $33 \%$ de inclinação, para manter os fluxos hidrológicos do córrego e oferecer espaço e acessibilidade para a população. Uma inclinação maior, de $50 \%$ deixa o solo exposto à erosão e também não é capaz de sustentar grandes vegetações ou atividades de recreação e transporte.

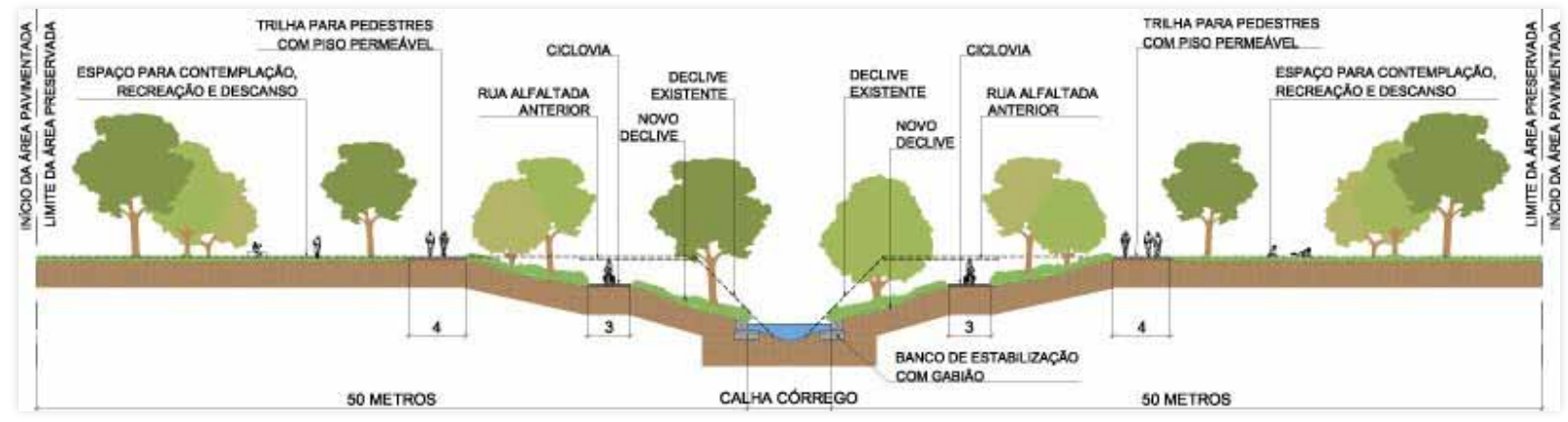

Figura 17: llustração: Corte esquemático de novo declive e o espaço proposto.

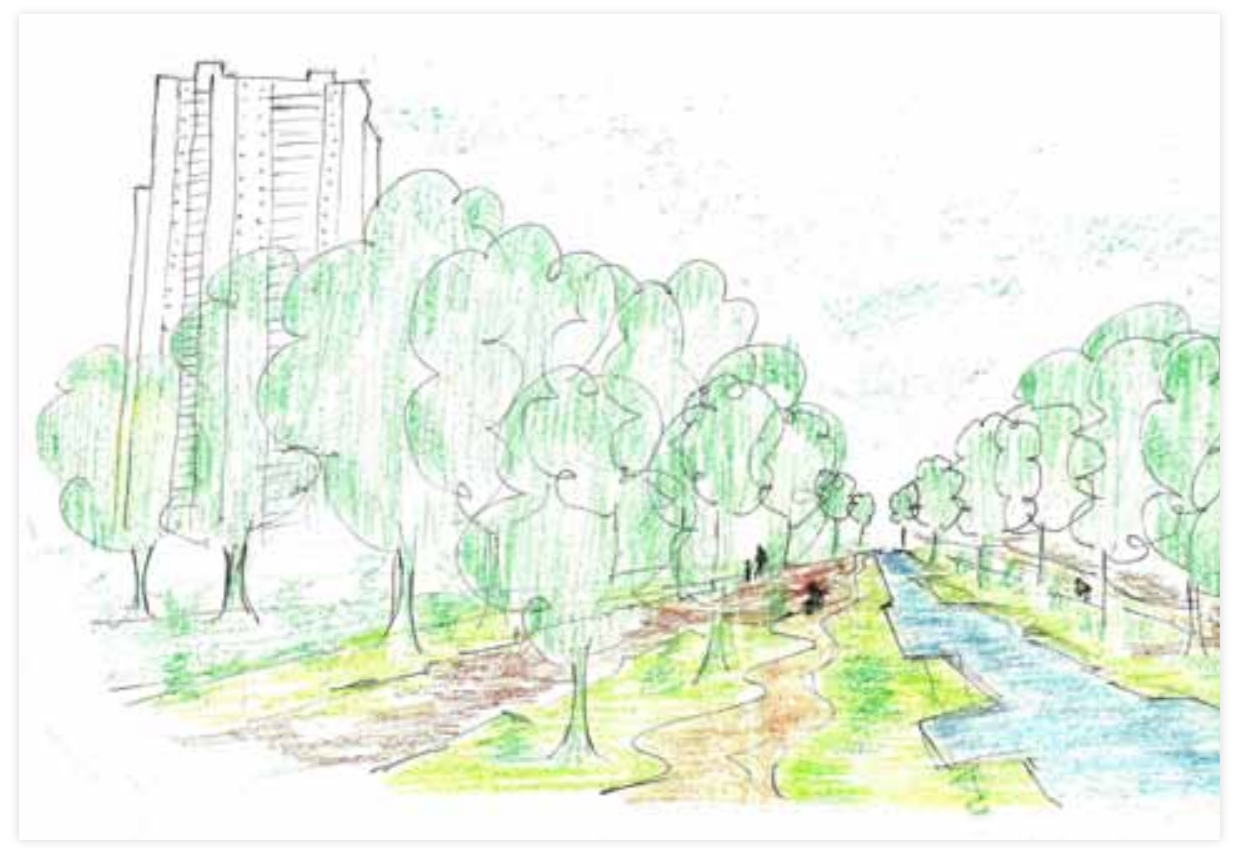

Figura 18: Ilustração: Croqui da área em estudo recuperada. Fonte: desenho dos autores 


\section{CONSIDERAÇÕES FINAIS}

A defasagem das cidades em infraestrutura verde faz com que ela sofra com a degradação do meio ambiente natural e conseqüente deterioração da saúde e qualidade de vida. Os córregos analisados neste trabalho de pesquisa, são tratados hoje como dutos e calhas de drenagem urbana. Suas margens estão muito íngremes, impossibilitando o uso para caminhada e bicicleta.

É necessário sensibilizar os diversos níveis de governo, a partir da Subprefeitura da Lapa, para que se possa verificar a importância de resgatar todo o potencial do ambiente natural, providenciando a desconstrução de áreas urbanizadas, salientando os exemplos reais que resultaram em ações altamente efetivas, positivas, como as apresentadas nos Estudos de Caso desta pesquisa. A inclusão de um corredor verde entre o Rio Tietê e o Parque da Água Branca, é essencial a ser considerado nos futuros projetos voltados à mobilidade sustentável.

Ao contrário do que se pensa atualmente, a "desconstrução" das cidades começa a mostrar sinais de força e a desencadear um processo irreversível; haja visto que nega a sua condição real; prenuncia uma nova imagem urbana, transformadora e aponta uma saída para o caos urbano em que se vive hoje na cidade.

\section{BIBLIOGRAFIA}

BONDUKI, Nabil; O Início da Política de habitação social no Brasil, FAUUSP, São Paulo, 1995.

CENÁRIOS AMBIENTAIS 2020 - São Paulo (Estado). Secretaria do Meio Ambiente / Coordenadoria de Planejamento Ambiental. Projeto Ambiental Estratégico. Coordenação Casemiro Tércio dos Reis Lima Carvalho e Renato Rosenberg - - São Paulo : SMA/CPLA, 2009.

CONSELHO NACIONAL DO MEIO AMBIENTE-CONAMA: Resolução n³05 de 12 de junho de 2002

DEAK, C. \& SCHIFFER, S. (orgs.). O processo de urbanização no Brasil. São Paulo: FUPAM/EDUSP, 1999; EMURB - Empresa Municipal de Urbanização/WALM-Enge- 
nharia e Tecnologia Ambiental, EIA - Estudo de Impacto Ambiental para a Operação Urbana Água Branca.

HARVEY, David : A Justiça Social e a Cidade, Hucitec, São Paulo, 1980.

: O Trabalho, o Capital e o Conflito de Classes em Torno do Ambien-

te Construído, nas Sociedades Capitalistas Avançadas, in Espaço \& Debates, $n^{\circ} 6$, jan. - set., 1982, p.6.

HUNG, Y. \& AQUINO, G.: Infrastructure Landscape-Cases studies by SWA, Birkhauser

LEI FEDERAL n 6938 DE 31 DE AGOSTO DE 1981 Da Política Nacional do Meio Ambiente

LEI FEDERAL nº 10.257 de 10 de julho de 2001 - Estatuto da Cidade.

LOMBARDO, Magda Adelaide: Ilha de Calor nas Metrópoles - Ed. Hucitec, São Paulo, 1985.

MARTINS, Maria Lucia R. Moradia e Mananciais: tensão e diálogo na Metrópole. São Paulo, FAUUSP / FAPESP, 2006. 206p

MINISTÉRIO DAS CIDADES, 2007a, PlanMob - Caderno de Referência para Elaboração de Plano de Mobilidade Urbana, Secretaria Nacional de Transporte e da Mobilidade Urbana, Brasília.

MINISTÉRIO DAS CIDADES, 2007b, Plano de Mobilidade por Bicicleta nas Cidades, Coleção Bicicleta Brasil, caderno 1, Secretaria Nacional de Transporte e da Mobilidade Urbana, Brasília.

MIRANDA, Hellem de Freitas: Mobilidade urbana sustentável e o caso de Curitiba São Carlos: EESC/USP, 2010

SILVEIRA, Mariana Oliveira da Mobilidade Sustentável: A bicicleta como um meio de Transporte integrado/ Mariana Oliveira da Silveira - Rio de Janeiro: UFRJ/COPPE, 2010.

SHUTZER, José Guilherme. Cidade e Meio Ambiente: A apropriação do relevo no desenho ambiental urbano.- São Paulo: Editora da Universidade de São Paulo,2012 
SAAE-Sorocaba - Serviço Autônomo de Água e Esgoto de Sorocaba, Programa de Despoluição do Rio Sorocaba, novembro 2011

VILLAÇA, Flavio. Espaço intra-urbano no Brasil. São Paulo: Nobel, 2001.

\section{REFERÊNCIAS}

http://www.anamma.com.br/mostra-imprensa.php?id=19 - Associação Nacional dos Órgão Municipais de Meio Ambiente, acesso em outubro de 2012.

http://arquiteturaurb.blogspot.com.br/2009/06/direito-de-preempcao.html http://www.ruaviva.org.br/mobilidade/index.html - Rua Viva, acesso em outubro 2012. http://sosriosdobrasil.blogspot.com.br/2009/05/rio-cheonggyecheon-na-coreia-do-sulum.html, acesso em outubro/2012.

http://www.nossasaopaulo.org.br/portal/node/2833, acesso em outubro/2012.

http://g1.globo.com/Noticias/SaoPaulo/0,,MUL1077177-5605,00-RIOS+E+CORREG $\mathrm{OS}+\mathrm{DE}+\mathrm{SP}+\mathrm{SAO}+\mathrm{TEMA}+\mathrm{DE}+\mathrm{SERIE}+\mathrm{ESPECIAL+DE}+\mathrm{REPORTAGENS}$.html, acesso em outubro/2012.

http://mobilidadesustentavel.blog.uol.com.br/arch2012-10-01_2012-10-31. html\#2012_10-02_16_15_04-146065311-0, acesso em outubro/2012.

http://www.saaesorocaba.com.br/site/?page_id=173, acesso em outubro/2012.

http://agencia.prefeiturasorocaba.com.br/noticia/22831, acesso em outubro/2012.

http://www.areasverdesdascidades.com.br/2012/07/jardim-botanico-de-sao-paulo. html, acesso em outubro/2012.

http://www.condepefi.sp.gov.br/noticias/80_anos_botanico/jardim_botanico_80_anos. htm, acesso em outubro/2012. 
http://www.ambiente.sp.gov.br/acontece/noticias/jardim-botanico-completa-80-anose-remodelado-e-recebe-homenagem-dos-correios/, acesso em outubro/2012.

http://www.portaldeinterlagos.com.br, acesso em outubro/ 2012.

http://saopaulo-sp-aac.blogspot.com.br/, acesso em outubro/2012. 